University of Wollongong

Research Online

Faculty of Business - Papers (Archive)

Faculty of Business and Law

2013

Enhancing the educational subject: cognitive capitalism, positive psychology and well-being training in schools

James Reveley

University of Wollongong, jreveley@uow.edu.au

Follow this and additional works at: https://ro.uow.edu.au/buspapers

Part of the Business Commons

Research Online is the open access institutional repository for the University of Wollongong. For further information contact the UOW Library: research-pubs@uow.edu.au 


\title{
Enhancing the educational subject: cognitive capitalism, positive psychology and well-being training in schools
}

\begin{abstract}
Positive psychology is influencing educational policy and practice in Britain and North America. This article reveals how this psychological discourse and its offshoot school-based training programs, which stress happiness, self-improvement and well-being, align with an emergent socioeconomic formation: cognitive capitalism. Three key points are made. First, there is an elective affinity between cognitive capitalism and positive psychology, whose advocates promote 'mindfulness','curiosity' and 'psychological flexibility' as the means to personal fulfilment. Second, an array of technologies of the self spring from the positive psychology discourse; mindfulness practice is one of these. Currently being trialled in British and North American schools, this self-technology exhorts children consciously to constitute themselves as curious, creative, self-regulating persons. Third, this discourse and its attendant self-transformative practices promote a reflexive subjectivity that cognitive capitalism actively exploits. Yet it is potentially a resistant subjectivity with the capacity to turn a blowtorch back upon this capitalism.
\end{abstract}

\section{Keywords}

era2015, enhancing, training, schools, educational, being, subject, well, cognitive, psychology, capitalism, positive

\section{Disciplines \\ Business}

\section{Publication Details}

Reveley, J. (2013). Enhancing the educational subject: cognitive capitalism, positive psychology and wellbeing training in schools. Policy Futures in Education, 11 (5), 538-548. 


\title{
Enhancing the Educational Subject: cognitive capitalism, positive psychology and well-being training in schools
}

\author{
JAMES REVELEY \\ School of Management and Marketing, \\ University of Wollongong, Australia
}

\begin{abstract}
Positive psychology is influencing educational policy and practice in Britain and North America. This article reveals how this psychological discourse and its offshoot school-based training programs, which stress happiness, self-improvement and well-being, align with an emergent socioeconomic formation: cognitive capitalism. Three key points are made. First, there is an elective affinity between cognitive capitalism and positive psychology, whose advocates promote 'mindfulness', 'curiosity' and 'psychological flexibility' as the means to personal fulfilment. Second, an array of technologies of the self spring from the positive psychology discourse; mindfulness practice is one of these. Currently being trialled in British and North American schools, this self-technology exhorts children consciously to constitute themselves as curious, creative, self-regulating persons. Third, this discourse and its attendant self-transformative practices promote a reflexive subjectivity that cognitive capitalism actively exploits. Yet it is potentially a resistant subjectivity with the capacity to turn a blowtorch back upon this capitalism.
\end{abstract}

Happiness is not a matter of science, but of ideology. (Berardi, 2009, p. 90)

Happiness is the process of developing our capacities of democratic decision making and training ourselves in self-rule. (Hardt \& Negri, 2009, p. 377)

The increase in psychologists', sociologists', and other 'self-help' experts' interventions ... [and] the explosion of 'care of the self techniques in society - these are symptoms of the new forms of individual government, which include, above all, the shaping of subjectivity. (Lazzarato, 2012, p. 95)

In this article, I catch the ball set in flight by Peters and Bulut (2011) in their path-breaking volume about education's connections with the new 'cognitive' variety of capitalism. Two of Michel Foucault's greatest insights are my starting point. 'The first, nestled within his groundbreaking The Archaeology of Knowledge, is that new forms of capitalism have as their concomitant new discourses (Foucault, 1972, pp. 66-70). The second concerns how, from the classical era to the present day, technologies of the self sink deep cultural hooks into individuals, encouraging them to constitute themselves as subjects. These socially supplied techniques range from Ancient Greek practices of self-examination to Christian confession, to contemporary therapeutic practices such as mindfulness meditation. The common thread is that they 'permit individuals to effect ... operations on their own bodies and souls, thoughts, conduct, and way of being, so as to transform themselves in order to attain a certain state of happiness, purity, wisdom', and so forth (Foucault, 2000, p. 225). Now more than ever, this self-transformation is susceptible to capitalist imperatives, given the extent to which capitalism has colonised subjectivity's seedbed - the everyday lifeworld (Hardt $\&$ Negri, 2009). In the following discussion, I connect the dots between the rising influence of positive psychology and its offshoot self-technologies within educational policy and practice, and the emergence of a new socio-economic formation: cognitive capitalism. 
I want to make one thing clear at the outset. I am not claiming that psychological discourse positive psychology specifically - plays the same role within cognitive capitalism as 'the function carried out by economic discourse in the practice of emergent capitalism' (Foucault, 1972, p. 69). Foucault had something more encompassing in mind. Rather, I identify how a set of what Foucault (1972, p. 68) calls 'non-discursive practices' (cognitive capitalism) and a germane discourse (positive psychology) fortuitously coincide. In line with Gerth and Mills' (1980, pp. 62-63) interpretation of Max Weber's work, notably The Protestant Ethic and the Spirit of Capitalism (Weber, 1930), I use the term 'elective affinity' in its Weberian sense to capture this serendipitous juxtaposition of ideas and economic arrangements, in which the ideas help to extend, develop and reinforce those arrangements. Weber was writing about the role of a religious discourse - Calvinism - in producing individuals attuned to Western rational capitalism. My point is that there is an elective affinity between positive psychology and cognitive capitalism, whereby the former creates subjects who are 'useful' to the latter.

Positive psychology is one discipline among many that have scientised and psychologised happiness - a development emblematised by a 2005 Time cover as 'The Science of Happiness'. [1] Commencing in 2006 under that banner, Dr Tal Ben-Shahar's positive psychology class has been called Harvard University's most popular course.[2] Positive psychology conferences, websites, textbooks and self-help manuals abound. Advocates promote 'mindfulness', 'curiosity' and 'psychological flexibility' as the means to personal fulfilment (Kashdan, 2010; Kashdan \& Rottenberg, 2010). This 'positive' discourse is articulated and circulated within networks of therapists and scholars. Academically, it is legitimated by a specialised scholarly journal (the Journal of Positive Psychology).

Positive psychology is highly practically generative discourse, having spawned an array of technologies of the self. One example is the values inventory, by which positive psychologists exhort people to clarify their deep-seated personal values.[3] The inventory functions as an empirical scaffold for a practice with an Ancient Greek cultural taproot, aptly described by Foucault (2000, p. 236) as 'looking and listening to the self for the truth within'. More importantly from the standpoint of educational policy, however, is a technology of the self called 'mindfulness practice'. Currently being trialled in British and North American schools, this bodily regime exhorts children consciously to constitute themselves as curious, creative, self-regulating persons. I will argue that positive psychological discourse and the attendant self- technology of mindfulness practice, in turn, promote soft skills formation and a reflexive subjectivity that cognitive capitalism exploits. The mindful, 'happy' person emanating from the school system is grist to the cognitive capitalist mill.

The discussion in my article proceeds as follows. First, I identify connections between cognitive capitalism's exploitative dynamic and the constitution of a new form of subjectivity. I then draw attention to the complementarity between this subjectivity and the types of persons that positive psychology calls into being. Next I discuss mindfulness training as a means by which the very subjectivity cognitive capitalism thrives on is currently being constituted in schools. I proceed to distinguish my argument, about positive psychology's affinity with cognitive capitalism, from recent critiques of this discourse's educational policy influence. After that, I juxtapose happy individuals as a system 'input' to cognitive capitalism with a politicised, collective form of human happiness as an 'output' of that system. A brief conclusion rounds off the discussion.

\section{Cognitive Capitalism and Reflexive Self-Production}

Following Moulier Boutang (2011, p. 9), I take cognitive capitalism to mean 'a third type of capitalism' emergent in the wake of industrial capitalism - the successor, in turn, to mercantile capitalism. The thesis of cognitive capitalism can be simply stated. Value creation in the industrial era was based on units of labour time expended within the firm's confines, the equivalence of which was, in the final instance, determined quantitatively by the market. By contrast, under cognitive capitalism, value increasingly derives from hard-to-quantify 'intelligent, inventive and innovative labour' that 'mobilises the cooperation of brains in networks' (Moulier Boutang, 2011, p. 55). This capitalism is spurred by the comparatively recent 'Triple Revolution of social networks, the internet, and mobile availability' (Rainie \& Wellman, 2012, p. 34). These networks are 
extensive, transcending markets and hierarchies alike. They sustain peer-based production, epitomised by crowdsourcing and other forms of 'open innovation' (Marjanovic et al, 2012).

Sociality is at the core of this capitalism, under which capital accumulation is based on knowledge and creativity' (Moulier Boutang, 2011, p. 56). To be sure, as Moulier Boutang is quick to point out, physical labour

does not disappear, but it loses its centrality in favour of a cooperation of brains in the production of the living by means of the living, via the new information technologies, of which the digital, the computer and the Internet are emblematic. (Moulier Boutang, 2011, p. 57)

Simply put, immaterial labour comes to the fore. To the extent that it 'creates not only material goods but also relationships and ultimately social life itself, this labour has to "become intelligent, become communicative, become affective' (Hardt \& Negri, 2005, p. 109). These are the properties that cognitive capitalism exploits.

It may seem paradoxical to say that positive psychology - a discourse which eschews material wealth as the source of human fulfilment and seeks to enhance people's emotional rather than purely intellectual faculties - has an affinity with a wealth-creating economic system that prizes 'intelligence'. Such a relationship nonetheless exists; it stems from two things. First, it is collective intelligence, as in the 'collective intelligence of the population', that cognitive capitalism transforms into 'a direct factor of production' (Moulier Boutang, 2011, p. 185). Such intelligence is developed through 'the pollination of social relations' which are inherently affective (Moulier Boutang, 2011, p. 165). Pollination occurs in a relational network, central to which is the subject's ability to connect with others. As Moulier Boutang (2011, p. 140) remarks, cognitive capitalism 'engages the affects and the brain as a whole' (my emphasis). Second, one of positive psychology's key tenets is that the reflexive attainment of positive emotional states renders the subject 'open' to new experiences; these, in turn, foster intellectual flexibility (Kashdan, 2010).

Probing and describing one's own emotions, and rendering oneself open to selftransformation both strike a chord with how cognitive capitalism constitutes selves. By siphoning value from human networks, this new variety of capitalism colonises the space 'where subjectivity is born and resides' - namely, that of 'ideas, codes, images, affects, and social relationships', as Hardt and Negri (2009, p. 172) put it so well. To the extent that subjectivity is produced in the same common space where network-based value creation occurs, the work of economic production is simultaneously subjectivity-altering self-production (Hardt \& Negri, 2009, pp. 172-173). This produces a 'biopolitical subject', in whom the desire and capacity for 'self-training' becomes second nature (Moulier Boutang, 2011, p. 160). On this point, Gorz (2010, p. 11) helpfully translates Moulier Boutang: 'The worker no longer presents himself as possessor only of his hetero-produced labour-power [that is to say, of predetermined capacities inculcated by the employer], but as having produced himself and continuing to produce himself (my emphasis). Gorz pushes the point further. By channelling Combes and Aspe (1998), he makes the link back to affectivity:

self-production is a necessary dimension of all immaterial labour and ... such labour tends to call on the same capacities and personal dispositions as free, non-work activities. Combes and Aspe write: "It is in this sense that we may speak of a "total mobilization" of capacities and dispositions, including the affective.' (Gorz, 2010, p. 16)

While this encapsulation of the reflexive selfs centrality to cognitive capitalism is wonderfully succinct, it nonetheless begs the following question: Are these 'capacities' and 'dispositions' naturally occurring or are they institutionally evoked, developed and coaxed into being by discourses and practices inherent to cognitive capitalism itself?

Jeremy Lane supplies a timely and forceful answer. He critiques Gorz's and Moulier Boutang's depiction of 'the affects and intellectual capacities that cognitive capitalism creates' as being full-formed and prior, pre-existing 'natural resources, external ... to that mode of accumulation'; Lane (2011, p. 506) instead maintains that these capacities are 'the defining characteristics of the form of subjectivity' that cognitive capitalism itself seeks to create. Channelling Deleuze, he then argues - correctly, in my view - that the school is one institution, among many, that operates 'to produce workers as creative, communicative, self-auditing subjects, engaged in an open-ended process of self-surveillance and self-improvement' (Lane, 2011, p. 506). He concludes that: 'A coherent theory of cognitive capitalism would ... have to pay greater 
attention to ... subject formation', especially how 'the subject is constructed ... long before they enter the workplace', specifically 'in the institutions of school, family, and the broader culture' (Lane, 2011, p. 507). This is where positive psychology can be factored back into the cognitive capitalist equation, by focusing on the technologies of the self that this discourse promotes. Of particular importance is mindfulness practice, a self-technology that stresses the development of personal 'flexibility' and 'resilience'. When undertaken in schools, as a form of training, mindfulness practice is one means by which self-improving subjects are created prior to their full deployment as value creators within the workplace and social factory at large.

\section{Positive Psychology's Flexible Subject}

Positive psychology's birth certificate is a special issue of American Psychologist, published in 2000. It was edited by Martin Seligman and Mihaly Csikszentmihalyi, who are credited with establishing the field (Kashdan \& Steger, 2011, p. 9). They talk about shifting from trying to rectify psychological deficits and 'repairing damage' to 'building positive qualities', including well-being, happiness and hope (Seligman \& Csikszentmihalyi, 2000, p. 5). As Huppert (2009, p. 108) puts it, positive psychologists are 'aiming to enhance well-being rather than merely reducing disorder'. 'This ideal is encapsulated by the positive psychological shibboleth of people 'flourishing' (Seligman, 2011). This is no small-scale project, for 'positive psychology ... claims to bring optimism and resilience to millions' (Cigman, 2012, p. 450). Huppert (2012) even advocates the goal of 'flourishing populations', which is suggestive of a Foucauldian governmentality regime.

Since its inception, positive psychology has burgeoned into a diverse field (Sheldon et al, 2011). In the rest of this section, therefore, I will focus only on the aspects of this discourse that target the reflexive selves cognitive capitalism exploits; and I will draw primarily upon the popular literature. In so doing, I take my lead from Anthony Giddens (1991, p. 85), who, in his seminal Modernity and Self-Identity, analyses how self-therapy - he is talking about self-help manuals - assists with the 'reflexive construction of self-identity'. But I take one step more. Performing selftherapeutic body disciplines produces a reflexive form of subjectivity that is not merely indicative or symptomatic of how self-identity has changed in late modernity, as Giddens maintains. Rather, cognitive capitalism, by its very logic, actively presses this subjectivity into its service.

To the extent that it draws value from the creative activity of individuals within digital networks, cognitive capitalism requires a certain 'openness of mind' (Gorz, 2010, p. 5). In other words, it values subjects who attune themselves to a range of creative possibilities - including transforming themselves. This resonates with the blandishments of positive psychologists who cajole people to become 'mindful'. As the leading positive psychologist Todd Kashdan's (2010) popularising book's title Curious? suggests, one of positive psychology's watchwords is 'curiosity'; another is 'openness'. His description of mindfulness shows how these qualities connect:

[Mindfulness] is characterized by curiosity, openness, and acceptance. When we are mindful, we maintain an inquisitive nature about the thoughts, feelings, behaviors, and events experienced in the present. This inquisitive nature allows us to be receptive and aware of all aspects of reality. (Kashdan, 2010, p. 29)

A person who is curious, open and mindful is 'psychologically flexible' (Kashdan, 2010, p. 13). By contrast, "[1]ack of curiosity is a breeding ground for ... [d]ogmatism and rigid thinking, which is the opposite of psychological flexibility' (Kashdan, 2010, p. 25). In a nutshell, being open and curious about one's own emotions and the emotions of others, and the experience of positive emotional states, broadens and strengthens the cognitive processes associated with creativity. As Kashdan explains:

The greatest advantage of curiosity is that by spending time and energy with the new, increased neurological connections are made possible. Facts and experiences are synthesized into a web, paving the way for greater intelligence and wisdom ... We become better at visualizing the relativity of seemingly disparate ideas, paving the way for greater creativity. It is the neurological equivalent of personal growth. (Kashdan, 2010, p. 57)

Hence, the positive psychological ideal type is one of 'an engaged and curious explorer, taking risks and being creative and innovative' (Kashdan, 2010, p. 116). 
Positive psychology is not purely focused on the subject's inner life. Emotional introspection is the key to the other-regarding behaviours prized by positive psychologists, who have much to say about how people form meaningful relationships (Lambert et al, 2011). Arguably, curiosity about one's own emotional states, and the ability to reflect on them, fosters sociality. In its popularising form, the basic argument runs as follows:

By being observant of what is going on inside them and around them, very curious people gain close proximity to their thoughts and feelings, and those of others, and this ability is also visible and highly regarded by others. (Kashdan, 2010, p. 137)

In short, positive psychology encourages people to transform themselves into curious explorers. The process of critical and open self-reflection that this discourse exhorts people to undertake accords with the creative and 'self-auditing' (in Lane's terms) subjects on whom cognitive capitalism draws. It is a subject who reflexively self-monitors, introspects and self-transforms; a subject for whom emotional regulation is the gateway to the creative deployment of the intellect, both individually and in relationships with others. In the following section, I identify complementarity between positive psychology and school-based enhancement regimes, on the one hand, and cognitive capitalism, on the other. My argument is that, due to the influence of positive psychological discourse on educational policy, this reflexive subjectivity is now being constituted within schools.

\section{Cultivating the Flexible Educational Subject}

The positive psychology movement has always had a proselytising impulse. It even has a manifesto, the function of which is not dissimilar to a political proclamation. As Hardt and Negri (2012, p. 1) presciently remark: 'Manifestos provide a glimpse of the world to come and also call into being the subject'. Named after the Mexican location of a 1999 gathering of scholars interested in positive psychology, the Akumal Manifesto lists as one of its goals: 'Spreading positive psychological principles and perspectives to the broader public. For example, positive psychology might be incorporated into high school psychology curricula or within public health initiatives'. [4] In the relatively short amount of time since that declaration, positive psychology has influenced educational policy and practice in Britain and North America (Ecclestone \& Hayes, 2009; Seligman, 2011). As Cigman (2012, p. 453) says with respect to Britain: 'the positive ideal is embodied in much contemporary policy making, intended to bring resilience, optimism, self-esteem and other "life skills" to children through national interventions'. A central feature is what the influential Blair-era British government policy director, Geoff Mulgan, describes as teaching soft skills: 'how to think creatively, how to collaborate, how to empathise' (cited in Cigman, 2012, p. 453). This is part of what Cigman (2012, p. 454) aptly terms 'the enhancement agenda in education'.

There is no better practical example of this agenda and positive psychology's traction than the well-being-enhancing mindfulness training programs introduced into schools in England and the USA over the last several years (Huppert \& Johnson, 2010; Meiklejohn et al, 2012). Displaced from its Buddhist origins, mindfulness has recently morphed into a psychologised and scholasticised form, and now has its own academic journal (simply titled Mindfulness). As scientistic discourses, mindfulness and positive psychology are joined at the hip. Huppert and Johnson (2010, p. 265) say that the notion of mindfulness is 'congruent with much of the theory and practice in positive psychology'. Practically, mindfulness training is a therapeutic tool that positive psychologists advocate and use.

The aim of school-based interventions is to inculcate mindfulness in the schoolchild. Huppert and Johnson (2010, p. 265) offer the following definition: 'With mindfulness, we deliberately observe and accept what is happening right now, in our bodies, minds and the world around us, with an attitude of gentle curiosity'. The training involves teaching bodily regimes, which Meiklejohn et al (2012) group under the banner of 'mindfulness practice'.[5] The formal version is 'mindfulness meditation', which

typically consists of initially directing attention to $\mathrm{a}[\mathrm{n}]$... attentional 'anchor'.

As one practices, it becomes apparent that the mind will repeatedly drift off the chosen

'anchor' into spontaneously arising thoughts, memories, feelings, or images. Upon noticing this 
drift, the practitioner brings his/her attention back repeatedly to the anchor. The intent is not to get rid of thoughts, feelings, or sensations. Rather, it is to cultivate a clearer awareness of direct moment to moment experience with acceptance and a kindly curiosity. (Meiklejohn et al, 2012)

This is not mere New Age nonsense or psychobabble. Huppert and Johnson (2010, p. 265) hypothesised that: 'Training in the conscious control of attentional resources ... is likely to have beneficial effects on learning, problem solving, decision-making and other cognitive processes'. Indeed, after conducting a meta-analytic review, Meiklejohn et al (2012) conclude that mindfulness training in schools improves not just 'social skills' and 'emotional regulation', but also cognitive skills, such as 'improvements in working memory, attention, [and] academic skills'. If Moulier Boutang (2011, p. 162) is correct, and if cognitive capitalism's main dynamic is the 'exploitation of the inventive force of living labour', these are high on the list of qualities that this capitalism exploits. From the standpoint of system reproduction, the challenge is

to keep living labour alive as a living force throughout the [productive] cycle if it wants to capture a part of the invention-power and hence divert it to its own profit ... exploitation has now become ... not that of the consumption of labour power, but its willingness to make itself available, its attentiveness and its ability to form new networks and to enter into cooperation, through the medium of computers linked together. (Moulier Boutang, 2011, p. 163)

This is the pointy end of the enhancement agenda. As Rainie and Wellman (2012, p. 9) note, connecting with others through digital networks is 'socially taxing'. Enhanced cognitive, social and emotion-regulating skills are part and parcel of the 'mental mobility' that cognitive capitalism requires (Moulier Boutang, 2011, p. 127). The positive psychology goal of fostering 'resilience' and 'grit' - two of the qualities that mindfulness practice seeks to elicit - fulfils cognitive capitalist subjects' need for inner 'reserves of strength' as they are exploited throughout 'the duration of their lives', while immersed in the very 'fabric of society' itself (Moulier Boutang, 2011, p. 164).

There is another way in which mindfulness training is consistent with the requirements of cognitive capitalism, quite apart from mindfulness training's role in cognitive and social skills formation. Mindfulness practice has a deep affinity with the contemporary notion of the self as 'a reflexive project' - something to be worked on agentially (Giddens, 1991, p. 75). Mindfulness is a technology of the self in which

the body participates in a very direct way in the principle that the self has to be constructed.

Bodily regimes ... are the prime means whereby the institutional reflexivity of modern social life

is focused on the cultivation ... of the body. (Giddens, 1991, p. 100)

Mindfulness meditation is one among many such bodily regimes - from kundalini yoga and t'ai chi to tantric sex, therapeutic djembe drumming and French parkour. What I am arguing is that mindfulness practice, when underpropped by positive psychology and institutionalised in education policy, additionally functions - albeit latently - to create the very types of persons who are cognitive capitalism's lifeblood. I am not suggesting that any form of determinism is at work here. As Gorz (2010, pp. 12-13) says: 'The subject is never socially given; she is ... given to herself as a being that has to make herself what she is. No one can exempt the subject from this task, nor force it upon her'. While the subject cannot be forced, he/she can be coaxed to fashion him-/herself in 'positive' ways - especially during the formative years of schooling. Through the medium of technologies of the self, this is just what the educational enhancement agenda seeks to do. The affinity between positive psychology and cognitive capitalism is more by fortuitous coincidence than design. Nonetheless, through the implementation within schools of a specific technology of the self - mindfulness bodily discipline - the positive discourse has begun to mesh in practice with exploitation under this capitalism. School-based mindfulness training calls into being the very kind of open, psychologically flexible, curious, value-creating subject on whom cognitive capitalism depends.

\section{Implications for Education Discipline Critiques of Positive Psychology}

I want to draw my discussion to a head by highlighting differences between my argument and recent work by others who critique the rising influence of positive psychology within the education policy-making arena. Despite the recent critical attention the rise of positive psychology has elicited 
from educational scholars, they tend to overlook two things: first, this discourse's intricate dovetailing with cognitive capitalist imperatives and, second, how its attendant mindfulness selftechnology can activate the potential for biopolitical resistance, which is inherent to the cognitive capitalist subject.

Positive psychology's rising influence within the educational policy arena has not gone unnoticed. Education scholars of various disciplinary stripes have been quick to critique it, and rightly so. For one, Clack (2012) maintains that positive psychology has an ideological agenda. It resides in positive psychology's promulgation of well-being as 'something the individual can control through correct management of their inner life', abstracted from larger socio-economic structures; this fits neatly with neo-liberal notions of freely choosing individuals as masters of their own destiny (Clack, 2012, p. 502). By the same token, Ecclestone (2011) argues that the institutionalisation of positive psychology within the educational system produces new forms of inequality. Interestingly, the author ties this process back to subject creation:

Preoccupation with emotional vulnerability fractures epistemologies that depict the self and knowledge as socially or linguistically constructed and then goes further, offering a view of the permanently vulnerable human subject. This diminished view turns knowledge and pedagogy inward to offer psychological or psychotherapeutic support. (Ecclestone, 2011, p. 108)

I find this notion of permanent vulnerability troubling because it seems to minimise the possibilities for resistance which, as Foucault (1979) reminds us, are ever present within every social system that seeks to constitute and control the subject. By contrast with Clack and Ecclestone, I want to suggest that positive psychology is not merely - or even primarily - an ideology that directs attention inwards to people's inner life, to the exclusion of wider socio-economic structures. This psychological discourse's primary system-reproducing function is not to perpetuate what sociologists call 'inequality' - either by ideologically mystifying capitalist social relations (à la Clack) or by dwindling down the human subject to a vulnerable emotional shell infilled by therapeutics (à la Ecclestone). There is, I believe, a more active self-constitution at work which cultivates resistant subjectivities - a process that the sociological preoccupation with vulnerability and inequality, as opposed to exploitation, obscures. In short, exploitation implies resistance, and all the more so given that exploitation in cognitive capitalism occurs throughout society, in subjectivity's seedbed, and is buttressed by self-technologies that foster the very intellectual and affective capacities on which political organising also depends. The mindfulness technology stemming from positive psychology is double-jointed, incorporating subjects into capitalism while simultaneously developing their resistance potential. I will use the remainder of this section to elaborate this point, as it seems to me to speak to the very contradictoriness of cognitive capitalism, about which Moulier Boutang (2011) writes in a more general way.

Like all forms of capitalism, value creation in the cognitive variety is predicated upon an active value transfer (exploitation). Through practices such as mindfulness training, positive psychological discourse calls into being types of persons with the cognitive and emotional skills, together with the self-monitoring and self-constituting properties, from which cognitive capitalism draws value in the social factory. Even an everyday activity like surfing the Web exposes casual Internet users to exploitation, in the specifically Marxian sense of value creation, and transforms them into citizen-labourers (Fuchs, 2010). Indeed, social media such as Facebook is inherently exploitative in Marxian terms (Rey, 2012). Social media users are an exploited commodity (Fisher, 2012). These Internet-based systems, as Marazzi (2011, p. 115) puts it, 'suck surplus labor by following citizen-workers through every moment in their lives'; cognitive capitalism is 'leaching vital resources from the multitudes'.

The other side of the cognitive capitalist coin, however, is the capacity for resistance - a potential that capitalism inbuilds within all biopolitical subjects. Hardt and Negri $(2009,2012)$ are very clear on this point, as are authors within the autonomist school of Marxism more generally. According to Paolo Virno (2004, p. 66), subjective capacities such as collective social and emotional intelligence and enhanced interpersonal skills are 'a pillar of the production of surplus-value', but also, simultaneously, they are replete with socially transformative potential as the basis for a multitudinous community. Rather than seeing the exploited subject as permanently vulnerable, educational scholars need to take more seriously the positive psychologists' claim that mindfulness really does increase resilience, emotional intelligence, mental mobility and flexibility. Furthermore, 
while these enhanced capacities are central to value creation and exploitation, they can create resistant subjectivities by raising political consciousness. From a feminist standpoint, Deborah Orr recognised this over a decade ago. She argues that school-based mindfulness training has 'liberatory potential', as a means by which to effect change in student learning 'on the levels of body, emotion, and spirit', so as to counter oppressive educational pedagogies and practices based on the 'mind/body binarism' (Orr, 2002, p. 480). Simply put, mindfulness can create an anti-oppressive pedagogy of the holistic leaner.

Orr's argument about mindfulness training's 'liberatory potential' is not inconsistent with theorisations of resistant subjectivities which spring from autonomist understandings of collaborative labour. This potential is inherent to the qualities that cognitive capitalism prizes, and to the biopolitical subject whom it creates by relocating production to the social realm where subjectivity itself resides. What I am saying, then, is that this self-technology creates the selfeducating, holistic and self-auditing subject whom cognitive capitalism exploits, but the intellectual and affective qualities of this subject can turn a resistance-based blowtorch back upon this capitalism. I turn now to explore this idea and its relationship with positive psychology's ultimate goal: human happiness.

\section{Institutionalising Collective Happiness}

Positive psychology's primary concern is with individual happiness. As I have argued, the atomised 'happy' subjects who emanate from schools are 'inputs' to cognitive capitalism - a source of labour in a production process that extends to society itself. Positive psychology thus is an individuating discourse which, due to its colonisation of educational policy, is functionally useful for this capitalism. In this section, I will contrast the individualisation of happiness in the service of capitalism with how the autonomists transpose happiness into a collective political end, and indeed locate its seeds within the very capitalism that positive psychology serves. In a nutshell, increasing collective happiness is one of cognitive capitalism's main structural tendencies - a system 'output', if you will. This propensity to increase collective happiness is intertwined with value production in this capitalism. At first blush, work by Moulier Boutang and Michel Bauwens speaks to this point. Each author writes about peer-based production, which is emblematic of how cognitive capitalism draws value from the multitude, and links it to increasing human happiness. Yet they remain stuck at the level of individual happiness, each subscribing to methodological individualism. After briefly reviewing their work, I will then make the link to collective happiness through the work of Hardt and Negri.

In a bracing article, Bauwens (2007) maintains that peer production, under a non-propertarian logic, directly increases the happiness of 'produsers' - the now standard sociological neologism that stands for the new Web 2.0-enabled subject. He is writing not just about the free software community, but also social media and other forms of participatory design, including the development of grass-roots community organisations and institutions. His point is that peer production is 'passionate production' which 'is based on voluntary engagement' free from external monitoring (Bauwens, 2007, p. 239). In order to clinch his argument, however, he draws on industrial psychology's stock-standard notion of intrinsic motivation, in which workers are motivated by interest in the tasks they perform. Hence, he writes of 'intrinsic positive "passionate" motivation' (Bauwens, 2007, p. 240). This harks back to the classic human relations movement's happy and motivated worker thesis, which, even when its advocates promoted team-based work, always was infused with an individualistic and regressive managerialism. Like positive psychology, Bauwens thus remains locked into a depoliticised and methodologically individualistic view of human happiness, under which community happiness is simply the aggregate sum of happy atomised - individuals. Indeed, somewhat worryingly given the neo-liberal undertone, Bauwens (2007, p. 242) lauds the fact that peer production avoids the need for 'time-consuming democratic negotiations' - the implication of which is clear: 'the individual can fully express himself and his capabilities' (my emphasis). The autonomist Franco 'Bifo' Berardi (2009, p. 91), it is worth noting, provides a stinging critique of this notion that atomistic 'free market play' in the Internet-based economy fosters maximal happiness. 
Despite his great insight into cognitive capitalism and his communitarian political philosophy, Moulier Boutang, it seems to me, operates within the economist's paradigm of methodological individualism, and thus - like Bauwens - is still writing about individual happiness. Moulier Boutang (2011) says that free software production is cognitive capitalism's prototypical 'model of production' (p. 83), the cooperative nature of which draws from the university and art worlds but is 'prey' to how value is systemically sucked from these creative activities (p. 130). Bracketing free software designers with 'the artist and the scholar', he labels it the paradigmatic example of creative labour and primary site of 'cognitive play' (Moulier Boutang, 2011, pp. 90-91). For him, this is one of cognitive capitalism's contradictory features. At the self-same time as value is being created and siphoned off, and the citizen-labourers thus exploited, the peer-based nature of this production opens a production space beyond the firm and market, which ushers in 'a reinstatement of utilitarian altruism (in other words, the pursuit of the happiness or utility of the greatest number of people)' (Moulier Boutang, 2011, p. 91).

In order to transpose the analysis up to the level of collective happiness, and to tease out the political implications of this aspect of cognitive capitalism, I return once more to Hardt and Negri. Their work shows that the creative and productive play which Moulier Boutang is writing about is not unique to software production (although may well be typified by it). There is a panoply of 'common goods, such as ideas, codes, affects [and] images', which the labouring subject produces under cognitive capitalism (Hardt \& Negri, 2009, p. 382).

Drawing on Enlightenment thinkers, Hardt and Negri (2009, p. 377) observe that individual happiness is friable; for a long-lasting effect, 'the multitude must govern itself in order to create a durable state of happiness' - namely, 'common happiness'. Happiness must be transposed into a 'political concept' (as opposed to a scientific one), which entails 'putting into action democratic government' (Hardt \& Negri, 2009, p. 376). Happiness thus becomes both a 'political and ontological project' (Hardt \& Negri, 2009, p. 379). These insightful observations lead me to this section's final point. Here it is: cognitive capitalism's production (i.e. value-creation) process has the inherent potential to qualitatively transform individual happiness into a collective, politicised form of happiness. If one accepts Hardt and Negri's (2009, p. 383) argument, value creation under cognitive capitalism entails the production of 'new and greater forms of the common', and forms of self-training that promote democracy. As such, cognitive capitalism's subjects are, by their very day-to-day actions, 'instituting happiness' (Hardt \& Negri, 2009, p. 378).

\section{Conclusion}

The founding fathers of Calvinism had no idea that their religious doctrine of predestination - the implications of which Weber analysed so masterfully in The Protestant Ethic and the Spirit of Capitalism - would help to develop a new form of (Western rationalising) capitalism. Likewise, the originators of positive psychology undoubtedly have no inkling that their discourse, as it is being institutionalised within schools, functions to prepare children for life under cognitive capitalism. There is a supreme irony at work. Ehrenreich (2009) shows that positive psychology has swung to the right, with strong links to neo-liberalism. It is a politically regressive discourse, yet one that has an elective affinity with cognitive capitalism - a system of production with an inbuilt radicalising and democratising impulse. Through the introduction into schools of the self-technologies that positive psychology advocates, together with cognitive capitalism's tendency to create resistant subjectivities, positive psychology may inadvertently assist with transforming society along the collectivist lines advocated by the left.

Indeed, there is no firm ideological barrier separating the reflexive self-transformation advocated by positive psychologists and the self-education of politically conscious 'singularities' called for by Hardt and Negri (2012, pp. 75-76). Cognitive capitalism's labouring subject is not perpetually vulnerable or powerless. Inherent to 'biopolitical' labour is the capacity for political action - the socially transformative potential to 'construct new social relationships, new forms of life that allow it to actualise its productive powers' (Hardt \& Negri, 2009, p. 152). For cognitive capitalism, therefore, positive psychology's curious explorer is a subject with a sting in its tail. 


\section{Notes}

[1] This cover appeared on the 17 January 2005 issue of Time. See http:/ / www.time.com/time/ covers/0,16641,20050117,00.html

[2] Ben-Shahar has his own website, on which he sells his books and now offers his own online courses (http:/ / www.talbenshahar.com/). On the popularity of his Harvard class, see 'The Most Popular Class at Harvard University: "Positive Psychology; The Science of Happiness"” at: http: / / camsolivia.hubpages.com/hub/The-Most-Popular-Class-at-Harvard-University-PositivePsychology-The-Science-of-Happiness

[3] For an example, see the inventory offered up by Kashdan (2010, pp. 97-99).

[4] On the origins of early positive psychology gatherings, see the website of the University of Pennsylvania's Positive Psychology Center at: http://www.ppc.sas.upenn.edu/ppgrant.htm\#Akumal. The Akumal Manifesto is reproduced as an appendix to Sheldon et al (2011). It is also available in full at: http:/ / www.ppc.sas.upenn.edu/akumalmanifesto.htm

[5] On the full range of mindfulness techniques, see the second chapter of Chaskalson (2011).

\section{References}

Bauwens, M. (2007) P2P and Human Happiness. http:/ / www.bhutanstudies.org.bt/ pubFiles/15.3rdGNH.pdf

Berardi, F. (2009) The Soul at Work: from alienation to autonomy. Los Angeles: Semiotext(e).

Chaskalson, M. (2011) The Mindful Workplace. Oxford: Wiley-Blackwell. http: / / dx.doi.org/10.1002/9781119976974

Cigman, R. (2012) We Need to Talk about Well-being, Research Papers in Education, 27(4), 449-462. http: / /dx.doi.org/10.1080/02671522.2012.690238

Clack, B. (2012) What Difference Does It Make? Philosophical Perspectives on the Nature of Well-being and the Role of Educational Practice, Research Papers in Education, 27(4), 497-512. http: / / dx.doi.org/10.1080/02671522.2012.690239

Ecclestone, K. (2011) Emotionally-Vulnerable Subjects and New Inequalities: the educational implications of an 'epistemology of the emotions', International Studies in Sociology of Education, 21(2), 91-113. http:/ / dx.doi.org/10.1080/09620214.2011.575100

Ecclestone, K. \& Hayes, D. (2009) Changing the Subject: the educational implications of developing emotional well-being, Oxford Review of Education, 35(3), 371-389. http: / / dx.doi.org/10.1080/03054980902934662

Ehrenreich, B. (2009) Bright-Sided: how the relentless promotion of positive thinking has undermined America. New York: Henry Holt.

Fisher, E. (2012) How Less Alienation Creates More Exploitation? Audience Labour on Social Network Sites, TripleC: Cognition, Communication, Cooperation, 10(2), 171-183.

Foucault, M. (1972) The Archaeology of Knowledge. New York: Pantheon Books.

Foucault, M. (1979) Discipline and Punish: the birth of the prison. New York: Vintage Books.

Foucault, M. (2000) Technologies of the Self, in P. Rabinow (Ed.) Ethics: subjectivity and truth-essential works of Foucault 1954-1984, pp. 223-251. London: Penguin.

Fuchs, C. (2010) Labor in Informational Capitalism and on the Internet, Information Society, 26(3), 179-196. http:/ / dx.doi.org/10.1080/01972241003712215

Gerth, H.H. \& Mills, C.W. (1980) From Max Weber: essays in sociology. New York: Oxford University Press. Giddens, A. (1991) Modernity and Self-Identity: self and society in the late modern age. Cambridge: Polity Press. Gorz, A. (2010) The Immaterial: knowledge, value and capital. London: Seagull Books.

Hardt, M. \& Negri, A. (2005) Multitude: war and democracy in the age of empire. New York: Penguin. Hardt, M. \& Negri, A. (2009) Commonwealth. Cambridge, MA: Belknap Press.

Hardt, M. \& Negri, A. (2012) Declaration. New York: Melanie Jackson Agency.

Huppert, F.A. (2009) A New Approach to Reducing Disorder and Improving Well-being, Perspectives on Psychological Science, 4(1), 108-111. http:/ / dx.doi.org/10.1111/j.1745-6924.2009.01100.x 
Huppert, F.A. (2012) From Flourishing People to Flourishing Populations. Paper presented at Third Australian Positive Psychology and Wellbeing Conference, Wollongong, 22-25 March.

Huppert, F.A. \& Johnson, D.M. (2010) A Controlled Trial of Mindfulness Training in Schools: the importance of practice for an impact on well-being, Journal of Positive Psychology, 5(4), 264-274. http:/ / dx.doi.org/10.1080/17439761003794148

Kashdan, T.B. (2010) Curious? Discover the Missing Ingredient to a Fulfilling Life. New York: Harper. http://dx.doi.org/10.1016/j.cpr.2010.03.001

Kashdan, T.B. \& Rottenberg, J. (2010) Psychological Flexibility as a Fundamental Aspect of Health, Clinical Psychology Review, 30, 865-878.

Kashdan, T.B. \& Steger, M.F. (2011) Challenges, Pitfalls, and Aspirations for Positive Psychology, in K.M. Sheldon, T.B. Kashdan \& M.F. Steger (Eds) Designing Positive Psychology: taking stock and moving forward, pp. 9-21. Oxford: Oxford University Press.

Lambert, N.M., Fincham, F.D., Marlea Gwinn, A. \& Ajayi, C.A. (2011) Positive Relationship Science: a new frontier for positive psychology? In K.M. Sheldon, T.B. Kashdan \& M.F. Steger (Eds) Designing Positive Psychology: taking stock and moving forward, pp. 280-292. Oxford: Oxford University Press.

Lane, J.F. (2011) Disaffection in the Post-Fordist Workplace: figurations of 'immaterial labour' in recent French theory and literature, Modern and Contemporary France, 19(4), 495-509. http:/ / dx.doi.org/10.1080/09639489.2011.610168

Lazzarato, M. (2012) The Making of the Indebted Man. Los Angeles: Semiotext(e).

Marazzi, C. (2011) The Violence of Financial Capitalism. Los Angeles: Semiotext(e).

Marjanovic, S., Fry, C. \& Chataway, J. (2012) Crowdsourcing Based Business Models: in search of evidence for innovation 2.0, Science and Public Policy, 39(3), 318-332. http:/ / dx.doi.org/10.1093/scipol/scs009

Meiklejohn, J. et al (2012) Integrating Mindfulness Training into K-12 Education: fostering the resilience of teachers and students, Mindfulness, 3(4), 291-307. http:/ / dx.doi.org/10.1007/s12671-012-0094-5

Moulier Boutang, Y. (2011) Cognitive Capitalism. Cambridge: Polity Press.

Orr, D. (2002) The Uses of Mindfulness in Anti-Oppressive Pedagogies: philosophy and praxis, Canadian Journal of Education, 27(4), 477-490. http:/ / dx.doi.org/10.2307/1602246

Peters, M.A. \& Bulut, E. (Eds) (2011) Cognitive Capitalism, Education and Digital Labor. New York: Peter Lang.

Rainie, L. \& Wellman, B. (2012) Networked: the new social operating system. Cambridge, MA: MIT Press.

Rey, P.J. (2012) Alienation, Exploitation, and Social Media, American Behavioral Scientist, 56(4), 399-420. http://dx.doi.org/10.1177/0002764211429367

Seligman, M.E.P. (2011) Flourish: a visionary new understanding of happiness and well-being. New York: Free Press.

Seligman, M.E.P. \& Csikszentmihalyi, M. (2000) Positive Psychology: an introduction, American Psychologist, 55(1), 5-14. http://dx.doi.org/10.1037/0003-066X.55.1.5

Sheldon, K.M., Kashdan, T.B. \& Steger, M.F. (2011) Designing Positive Psychology: taking stock and moving forward. Oxford: Oxford University Press. http://dx.doi.org/10.1093/acprof:oso/9780195373585.001.0001

Virno, P. (2004) A Grammar of the Multitude: for an analysis of contemporary forms of life. Los Angeles: Semiotext(e).

Weber, M. (1930) The Protestant Ethic and the Spirit of Capitalism. London: Unwin Hyman.

JAMES REVELEY is Associate Professor of Management at the University of Wollongong, NSW, Australia. His research interests broadly centre on the changing nature of education, work and organisation in new forms of capitalism, including the cognitive variety. He is the author of more than 20 refereed articles published in journals such as Human Relations, Culture and Organization, Journal of Management Studies, and Science \& Society. He is a member of the editorial board of Knowledge Cultures. His current research focuses on the economic and political implications of digital labour. Correspondence: jreveley@uow.edu.au 